\title{
Frequency of obesity and related risk factors among school children and adolescents in a low-income community. A cross-sectional study
}

Frequência de obesidade e fatores de risco relacionados em escolares e adolescentes em uma comunidade de baixa renda. Um estudo transversal

\author{
Mariana Carvalheiro Cotrim Lima', Ceres Concilio Romaldini", João Hamilton Romaldini"'" \\ Hospital do Servidor Público Estadual (HSPE), Instituto de Assistência Médica ao Servidor Público Estadual (IAMSPE), São Paulo, Brazil
}

\begin{abstract}
'Master's Student, Postgraduate Health Science Program, Hospital do Servidor Público Estadual (HSPE), Instituto de Assistência Médica ao Servidor Público Estadual (IAMSPE), São Paulo, Brazil. "MD, PhD. Professor, Postgraduate Health Science Program, Hospital do Servidor Público Estadual (HSPE), Instituto de Assistência Médica ao Servidor Público Estadual (IAMSPE), São Paulo, Brazil.

"'MD, PhD. Titular Professor of Endocrinology, Pontifícia Universidade Católica de Campinas (PUC-Campinas), and Professor, Postgraduate Health Science Program, Hospital do Servidor Público Estadual (HSPE), Instituto de Assistência Médica ao Servidor Público Estadual (IAMSPE), São Paulo, Brazil.
\end{abstract}

\section{KEY WORDS:}

Obesity.

Risk factors.

Nutritional status.

Cardiovascular diseases.

Lipids.

\section{PALAVRAS-CHAVE:}

Obesidade.

Fatores de risco.

Estado nutricional.

Doenças cardiovasculares.

Lipídeos.

\begin{abstract}
CONTEXT AND OBJECTIVE:The frequency of obesity at an early age may contribute to atherosclerosis and cardiovascular disease (CVD) in adults. This study measured the frequency of obesity and cardiovascular risk factors in children and adolescents aged 6 to 17 years.

DESIGN AND SETTING: Cross-sectional study in a school located in a region of low income and socioeconomic status in Santa Rita do Sapucai, Minas Gerais, Brazil.

METHODS: A total of 175 students were classified using body mass index (BMI) and their waist circumference, blood pressure, number of hours of sedentary behavior and school meals were evaluated. Serum concentrations of fasting blood glucose, total cholesterol (TC), triglycerides (TG), low-density lipoprotein ( $\mathrm{LDL}-\mathrm{C})$ and high-density lipoprotein ( $\mathrm{HDL}-\mathrm{C})$ were analyzed.

RESULTS: $37.2 \%$ of the students had BMI above the $85^{\text {th }}$ percentile and had significantly lower age, higher prevalence of hypertension, higher serum TC, LDL-C and TG, and greater waist circumference than those with BMI below the $85^{\text {th }}$ percentile. Hypertension was observed in $2.9 \%$ of the students; $5.1 \%$ presented impaired glucose tolerance, $40 \%$ had two risk factors for atherosclerosis and $26.9 \%$ had three risk factors. A sedentary lifestyle was significantly less prevalent among subjects with BMI above the $85^{\text {th }}$ percentile and was significantly correlated with serum TC and LDL-C. The school meals were hypoglycemic, hyperproteic and hyperlipidemic.

CONCLUSION: One third of the children and adolescents had weights greater than or equal to the ageadjusted weight, and this was associated with greater waist circumference, hypertension and prevalence of dyslipidemia.
\end{abstract}

\section{RESUMO}

CONTEXTO E OBJETIVO: A frequência de obesidade em idade precoce pode contribuir para a aterosclerose e doença cardiovascular (DCV) em adultos. Este estudo mediu a frequência de obesidade e fatores de risco cardiovascular em crianças e adolescentes com idades entre 6 e 17 anos.

TIPO DE ESTUDO E LOCAL: Estudo transversal em escola localizada numa região de baixa renda e baixo nível socioeconômico em Santa Rita do Sapucaí, Minas Gerais, Brasil.

MÉTODOS: Um total de 175 alunos foi classificado pelo índice de massa corporal (IMC) e foram aferidas circunferência da cintura, pressão arterial, horas de sedentarismo e alimentação escolar. Realizaram-se dosagens séricas de glicemia de jejum, colesterol total (CT), triglicerídeos (TG), lipoproteína de baixa densidade (LDL-C) e lipoproteína de alta densidade (HDL-C).

RESULTADOS: 37,2\% dos alunos tinham IMC acima do percentil 85 e apresentaram idade significativamente menor, prevalência mais alta de hipertensão, CT sérico, LDL-C e TG elevados e maior circunferência abdominal em comparação com aqueles com IMC abaixo do percentil 85. Observou-se hipertensão em 2,9\% dos estudantes, 5,1\% apresentavam tolerância à glicose diminuída, 40\% tinham dois fatores de risco para aterosclerose, e 26,9\% tinham três fatores de risco. O sedentarismo foi significativamente menor em indivíduos com IMC acima do percentil 85 e foi significativamente correlacionado com as concentrações séricas de CT e LDL-C. A merenda escolar estava hipoglicêmica, hiperproteica e hiperlipídica.

CONCLUSÃO: Um terço das crianças e adolescentes avaliados tinham pesos iguais ou superiores ao peso ajustado à idade, e isso foi associado a maiores circunferência abdominal, hipertensão e prevalência de dislipidemia. 


\section{INTRODUCTION}

Cardiovascular disease (CVD) is preceded by atherosclerosis, which is characterized by formation of plaque containing calcified necrotic nuclei, accumulation of lipids and leukocytes, and smooth muscle inflammation. ${ }^{1}$ This plaque develops through atheromatous deposits within arterioles and arteries that appear early in life, primarily in overweight children and adolescents. ${ }^{2}$ Approximately one third of all deaths worldwide and $85 \%$ of deaths in low and middle-income populations are attributed to CVD. ${ }^{3}$ In Brazil, similar to the situation in other developing countries, there are 300 deaths for CVD for every 100,000 inhabitants, ${ }^{4}$ and $30 \%$ of these deaths are related to atherosclerosis. ${ }^{5,6}$ Some patients may have one or more CVD risk factors, such as hypertension, diabetes mellitus, hyperinsulinemia, smoking, dyslipidemia or low physical inactivity. However, all of these factors can be prevented during childhood and adolescence.

In a study on 109 children and adolescents with a family history of premature CVD, $38.5 \%$ of the subjects had dyslipidemia alone or in association with atherosclerosis risk factors such as physical inactivity, hypertension, obesity and smoking. Overweight children and adolescents had a 2.8-times greater risk of developing dyslipidemia, and $72.5 \%$ of the patients affected did not exercise. ${ }^{7}$ Another cohort study showed that weight change during a 10-year follow-up correlated with physical activity. Lower activity was associated with greater gains in body weight, and increasing weight induced a further decrease in physical activity, thus forming a vicious circle. ${ }^{8}$ Furthermore, a study conducted in the United States noted that childhood measurements of serum lipoprotein, hypertension and body mass index (BMI) predicted carotid artery intima-media thickness in young adults. ${ }^{9}$ Collectively, these data suggest that the presence of CVD risk factors in childhood and adolescence may contribute to atherosclerosis development in adults.

The frequency of obesity in Brazil has increased over the last 30 years. ${ }^{10}$ This raises great concern because this increase has been observed from a very early age and at all socioeconomic levels. ${ }^{11,12}$ Thus, early diagnosing of obesity is important for establishing preventive measures ${ }^{13,14}$ that could avoid later development of long-term comorbidities. ${ }^{15}$

\section{OBJECTIVE}

The purpose of the present study was first, to evaluate the frequency of overweight and obesity among children and adolescent students in a region of low socioeconomic status; and second, to investigate the possible CVD risk factors (obesity, dyslipidemia, hypertension, large abdominal circumference, high blood glucose and physical inactivity) associated with the nutritional status determined from the BMI.

\section{METHODS}

This cross-sectional study was conducted in a municipal school in the urban area of Santa Rita do Sapucaí, Minas Gerais, which has a population of 37,754 inhabitants. ${ }^{16}$ The participating students were aged between six and 17 years, and the parents or guardians of the children provided informed consent. The exclusion criteria included presence of hypothyroidism, nephrotic syndrome, chronic renal failure or liver diseases and use of corticosteroids, beta-blockers or anabolic steroids. ${ }^{17}$

The study was approved by the Research Ethics Committee of our institution, Instituto de Assistência Médica ao Servidor Público Estadual (IAMSPE). All parents or legal guardians of the participants provided informed written consent prior to inclusion of students in the study.

Family income data were obtained at the time when the students were examined. The maximum income was one minimum monthly wage per capita (equivalent to US\$ 308), thus constituting low income and socioeconomic status. A questionnaire on their family story status was completed by one of the authors (MCCL) including information about CVD, diabetes mellitus and hypertension.

A thorough family history was taken by two of the authors (MCCL and CCR), focusing on coronary artery disease, diabetes mellitus and hypertension, along with the child's history of physical activity and number of hours of sedentary behavior. Time spent on sedentary activities was defined as the number of hours per day spent on activities that do not involve participation in physical activity, including watching television, playing video games, using the computer or no activity. ${ }^{18}$

Body weight was measured on a digital scale with a precision of $0.100 \mathrm{~kg}$. Height was measured by means of a stadiometer, in accordance with Bolzan et al. ${ }^{19}$ BMI was determined using the WHO AnthroPlus software, version 3.2.2, in accordance with the World Health Organization (WHO) reference standard. ${ }^{20}$ The results were expressed as percentiles $(\mathrm{P})$ : severely wasted $(\mathrm{P}<0.1)$, wasted $(\mathrm{P}>0.1$ and $\mathrm{P}<0.3)$, eutrophic $(\mathrm{P} \geq 3$ and $\mathrm{P}<85)$, overweight $(\mathrm{P} \geq 85$ and $P<97)$, obese $(P \geq 97$ and $P<99.9)$ and severely obese $(P \geq 99.9)$.

Waist circumference was measured at the midpoint between the lower rib and the iliac crest using a nonelastic flexible tape measure, with the subject in a standing position and the waist unclothed. ${ }^{21}$ Abdominal obesity was diagnosed when the circumference was greater than or equal to the $90^{\text {th }}$ percentile. ${ }^{22}$

Measurements of blood pressure were adjusted for age, height and gender and were made with the subject in a seated position after a five-minute rest. ${ }^{23}$ The systolic blood pressure (SBP) and diastolic blood pressure (DBP) were categorized into four percentiles for children and adolescents as follows: normal $\left(<90^{\text {th }}\right.$ percentile); prehypertension (SBP and/or DBP between the $90^{\text {th }}$ and $95^{\text {th }}$ percentiles); hypertension stage 1 (SBP and/or 
DBP between the $95^{\text {th }}$ and $99^{\text {th }}$ percentiles); and hypertension stage 2 (SBP and/or DBP $\geq 99^{\text {th }}$ percentile)..$^{23}$

The nutritional quality of the school meals was analyzed on three alternate days by one of the authors (MCCL), in relation to the standards of the National School Meals Program (Programa Nacional de Alimentação Escolar, PNAE) and the Brazilian Institute for Geography and Statistics (Instituto Brasileiro de Geografia e Estatística, IBGE). ${ }^{24}$

Peripheral blood samples were collected after overnight fasting by a nurse in vacuette tubes, serum was separated and the biochemical analysis was performed in the same day at the clinical laboratory (Miranda Reis, Santa Rita do Sapucaí, Minas Gerais). The serum concentrations of glucose, total cholesterol (TC), triglycerides (TG), low-density lipoprotein (LDL-C), very low-density lipoprotein (VLDL-C) and high-density lipoprotein (HDL-C) were measured from blood samples taken after 12 hours of fasting. TC and HDL-C were measured by means of an enzymatic colorimetric cholesterol esterase method; TG was also measured using an enzymatic colorimetric method. LDL-C was calculated using the Friedewald formula. Diabetes was defined as fasting glucose greater than or equal to $126 \mathrm{mg} / \mathrm{dl}$; fasting glucose between 100 and $125 \mathrm{mg} / \mathrm{dl}$ was defined as impaired glucose tolerance. ${ }^{25}$ The serum lipid reference values followed the first Brazilian guidelines for prevention of atherosclerosis in childhood and adolescence: TC $<170 \mathrm{mg} / \mathrm{dl}$; TG $<130 \mathrm{mg} / \mathrm{dl}$; LDL-C < $130 \mathrm{mg} / \mathrm{dl}$; and HDL-C > $45 \mathrm{mg} / \mathrm{dl} .{ }^{26}$

All the participants were informed of the test results and were referred for outpatient care when indicated.

Descriptive analyses were stratified according to gender and BMI ( $\geq 85^{\text {th }}$ percentile and $\leq 85^{\text {th }}$ percentile). In the bivariate analysis, multiple comparisons were performed using the $t$ test and chi-square test. Multiple comparisons were analyzed using the analysis of variance (ANOVA) test. After confirming a Gaussian sample distribution, linear regression analysis (Pearson correlation) was performed. Significance was designated at 5\% for all analyses. The GraphPad Prism 5.01 for Windows software was used for all these analyses (GraphPad Software, Inc., CA, USA).

\section{RESULTS}

Out of 309 students invited, 175 students and their parents (56.6\%) agreed to participate. The reminder 134 (43.3\%) declined to participate or we were not able to obtain the signed consent. A total 175 children and adolescents were enrolled, comprising 107 females (61.1\%) and 68 males (38.9\%). Their ages ranged from 5.9 to 17.4 years with a mean age of $11.9 \pm 2.1$ years ( \pm standard deviation, SD). When the subjects were stratified according to gender and state of puberty, we did not find any difference in the BMI (Fisher exact test, $\mathrm{P}=0.06$ ), but the percentage of males with $\mathrm{BMI}>85^{\text {th }}$ percentile $(42.65 \%)$ was significantly higher (Fisher exact test, $\mathrm{P}=0.011$ ) than the percentage of females $(23.36 \%)$.
CVD, diabetes and hypertension were observed in 48\%, 49.6\% and $62.4 \%$ of the participants, respectively. High blood pressure (stages I and II) was observed in $2.9 \%$ of the students; $5.1 \%$ met the criteria for impaired glucose tolerance, but no cases of diabetes mellitus were diagnosed. Dyslipidemia was found in $6.3 \%$ of the subjects with high TC; $2.3 \%$ with elevated LDL-C; $1.1 \%$ with elevated TG; and $89.7 \%$ with $\mathrm{HDL}-\mathrm{C}$ less than $45 \mathrm{mg} / \mathrm{dl}$. BMI above the $85^{\text {th }}$ percentile was found in $37.2 \%$ of the students. Furthermore, $7.1 \%$ presented at least one atherosclerosis risk factor, and two, three, four and five risk factors were found in $40 \%, 26.9 \%, 12.6 \%$ and $3.4 \%$ of the subjects, respectively. A total of $61.1 \%$ of the subjects had normal weight; $15.4 \%$ were overweight, while $16.0 \%$ were obese and $4.6 \%$ were severely obese. Only $0.6 \%$ of the subjects were classified as severely wasted and $2.3 \%$ as wasted.

As summarized in Table 1, students with BMI greater than or equal to the $85^{\text {th }}$ percentile had significantly lower age, hypertension, elevated serum TC, LDL-C and TG, and greater waist circumference than shown by individuals with BMI less than the $85^{\text {th }}$ percentile. However, a sedentary lifestyle was observed significantly less frequently among subjects with BMI greater than or equal to the $85^{\text {th }}$ percentile, and the serum HDL-C and glucose levels were not different between the two groups.

In subjects with $\mathrm{BMI}$ greater than or equal to the $85^{\text {th }}$ percentile, the serum TC and LDL-C levels were significantly higher than those observed in subjects with BMI less than the $85^{\text {th }}$ percentile, as summarized in Table 2 .

In males who had reached puberty and whose BMI was greater than or equal to the $85^{\text {th }}$ percentile, we found that the TC levels were significantly higher $(21.05 \%)$ than in males who had reached puberty and whose $\mathrm{BMI}$ was less than the $85^{\text {th }}$ percentile (2.78\%; chi-square test, $\mathrm{P}=0.028)$.

In all the subjects, the serum TC and LDL-C concentrations were significantly correlated with the amount of time spent doing sedentary activities (Table 3 ).

The school meals were primarily hypoglycemic $(53.1 \%$, rather than the recommended $63 \%$ ), hyperproteinemic (15.6\%, rather than the recommended $12.5 \%$ ), and hyperlipidemic (31.3\%, rather than the recommended $22.5 \%$ maximum). Furthermore, while the calcium concentration (72.6\%) and magnesium concentration (82.0\%) did not reach the daily recommendations, ${ }^{24}$ the iron (103\%), zinc (233\%), sodium (526.1 mg), vitamin A (178\%) and vitamin C (201\%) concentrations met the nutritional recommendation and did not exceed the UL (maximum recommended dose). ${ }^{27}$ The dietary saturated fat level exceeded $2.8 \%$ of the nutritional recommendation.

\section{DISCUSSION}

The increase in the proportion of overweight children and adolescents over recent decades is an indication of comorbidities relating to obesity in adulthood..$^{10}$ In the present study, $36 \%$ of the subjects were 
Table 1. Clinical and laboratory results of the two groups of individuals separated according to body mass index (BMI)

\begin{tabular}{lccc|} 
& BMI $\geq 85^{\text {th }}$ percentile & BMI $\leq 85^{\text {th }}$ percentile & P-value \\
\hline Number of patients (\%) & $64(36.57 \%)$ & $111(63.43 \%)$ & - \\
\hline Age (years) & $11.37 \pm 2.359$ & $12.30 \pm 1.957$ & 0.002 \\
Diastolic blood pressure $(\mathrm{mmHg})$ & $106.47 \pm 14.697$ & $98.96 \pm 10.799$ & 0.001 \\
Systolic blood pressure $(\mathrm{mmHg})$ & $62.49 \pm 9.596$ & $56.15 \pm 8.512$ & 0.0001 \\
Body mass index (BMI) & $25.00 \pm 4.668$ & $17.84 \pm 2.48$ & 0.001 \\
Cholesterol $(\mathrm{mg} / \mathrm{dl})$ & $136.9 \pm 3.457$ & $128.1 \pm 2.397$ & 0.0338 \\
\hline Triglycerides $(\mathrm{mg} / \mathrm{dl})$ & $84.53 \pm 2.634$ & $77.99 \pm 1.400$ & 0.0171 \\
LDL-C $(\mathrm{mg} / \mathrm{dl})$ & $83.97 \pm 2.376$ & $75.27 \pm 2.360$ & 0.0166 \\
HDL-C $(\mathrm{mg} / \mathrm{dl})$ & $37.63 \pm 0.6732$ & $36.51 \pm 0.4219$ & 0.1381 \\
\hline VLDL $(\mathrm{mg} / \mathrm{dl})$ & $16.69 \pm 4.132$ & $15.55 \pm 3.055$ & 0.167 \\
\hline Glycemia $(\mathrm{mg} / \mathrm{dl})$ & $90.66 \pm 8.554$ & $89.53 \pm 7.039$ & 0.565 \\
\hline Sedentary behavior (hours) & $3.42 \pm 1.496$ & $4.27 \pm 2.493$ & 0.008 \\
\hline Abdominal circumference $(\mathrm{cm})$ & $79.5+1.6$ & 63.10 .8 & 0.001 \\
\hline
\end{tabular}

LDL-C = low-density lipoprotein-cholesterol; HDL-C = high-density lipoprotein-cholesterol; VLDL = very low-density lipoprotein.

Table 2. Lipid distribution according to body mass index (BMI) group

\begin{tabular}{|c|c|c|c|}
\hline Lipids & $\mathrm{BMI} \geq 85^{\text {th }}$ percentile & $\mathrm{BMI} \leq 85^{\text {th }}$ percentile & $P$-value* $(P=0.002)$ \\
\hline \multicolumn{4}{|c|}{ Total cholesterol } \\
\hline Desirable & $39(60.9 \%)^{\dagger}$ & $89(80.2 \%)$ & \multirow{2}{*}{$8.327(P=0.01)$} \\
\hline Borderline & $18(28.1 \%)$ & $18(16.2 \%)$ & \\
\hline \multicolumn{4}{|c|}{ LDL-cholesterol } \\
\hline Desirable & 48 (75.0\%) & 95 (85.6\%) & $7.971(P=0.018)$ \\
\hline \multicolumn{4}{|c|}{ HDL-cholesterol } \\
\hline Desirable & $13(20.3 \%)$ & $5(4.5 \%)$ & \multirow[t]{2}{*}{$1.004(>0.05)$} \\
\hline Low & 51 (79.7\%) & $106(95.5 \%)$ & \\
\hline \multicolumn{4}{|l|}{ Triglycerides } \\
\hline Desirable & $51(79.7 \%)$ & $98(88.3 \%)$ & $4.709(>0.05)$ \\
\hline
\end{tabular}

${ }^{*}$ Chi-square test; ${ }^{+}$Number of subjects and percentages in parentheses. $\mathrm{BMI}=$ body mass index; $\mathrm{LDL}=$ low-density lipoprotein; $\mathrm{HDL}=$ high-density lipoprotein.

Table 3. Correlations between history of time spent doing sedentary activities (measured in hours) and some clinical laboratory parameters

$\begin{array}{lccc}\text { Variable } & \text { All subjects } & \text { BMI } \geq 85^{\text {th }} \text { percentile } & \text { BMI } \leq 85^{\text {th }} \text { percentile } \\ \text { Total cholesterol } & -0.341(P=0.0006)^{*} & 0.164 & -0.344(P=0.002) \\ \text { LDL-cholesterol } & -0.246(P=0.006) & -0.006 & -0.355(P=0.01) \\ \text { Triglycerides } & -0.01 & -0.01 & 0.11 \\ \text { BMI } & -0.15 & -0.164 & 0.11(P>0.05)\end{array}$

$\mathrm{LDL}=$ low-density lipoprotein; $\mathrm{BMI}=$ body mass index; ${ }^{*}$ Pearson correlation.

overweight, and $48 \%$ had a family history of risk factors for CVD and atherosclerosis. ${ }^{8,22}$ Several studies have confirmed that excess weight is a risk factor for CVD. ${ }^{8,22,23}$ Results similar to those of the present study were observed in a study on 3063 children and adolescents, which found that $38.4 \%$ were overweight and obese ${ }^{28}$ and that this correlated with increased levels of metabolic diseases and CVD at an early age. ${ }^{29}$

There is a clear correlation between changes in lipoproteins and obesity, and with the onset and severity of childhood atherosclerosis. ${ }^{30}$ The present data were similar to those described by Rover ${ }^{31}$ and Costa, ${ }^{32}$ except for the HDL-C results. The mean TC found in the study by Scherr ${ }^{33}$ was similar to that of the present study. Another study revealed that there were significant differences in all serum lipid parameters between eutrophic, overweight and obese children and adolescents. ${ }^{28}$

The frequency of higher BMI in males than in females may be associated with early sexual maturation. ${ }^{13}$ Overweight explained 
the elevated TC levels in males who had reached puberty and whose BMI was greater than or equal to the $85^{\text {th }}$ percentile..$^{28,31}$

We found that students with a BMI greater than or equal to the $85^{\text {th }}$ percentile had significantly elevated DBP and SBP. This was recently also observed in a study on overweight and obese children, ${ }^{33}$ and has been correlated with a fourfold greater risk of hypertension in adulthood. ${ }^{23}$ During physical activity, the adrenergic system becomes more stable and, as a result, serum TG, LDL-C and VLDL-C concentrations decrease while HDL-C increases. ${ }^{28,34}$ Physical activity also increases cardiac muscle oxygen consumption and improves peripheral microvascular perfusion, thereby preventing atherosclerosis. ${ }^{34}$ The correlation between sedentary behavior and serum TC and LDL-C levels observed in the students with BMI greater than the $85^{\text {th }}$ percentile suggests that increased physical activity has a positive effect on these parameters and on weight. ${ }^{28,35-39}$

The nutritional quality of school meals may also negatively contribute to the present findings because of their high fat content, which may gradually increase the serum lipid profile in these students. On the other hand, we did not have access to data on family meals.

\section{CONCLUSIONS}

One third of the children and adolescents living in this lowincome and low socioeconomic status community were at or above the recommended age-adjusted weight, which was associated with greater waist circumference, hypertension and dyslipidemia. In addition to dietary change, a decrease in sedentary behavior should be encouraged. These interventions should be implemented at an early age in order to avoid obesity and sedentary behavior later on, thereby decreasing the likelihood of atherosclerosis and CVD in adulthood.

\section{REFERENCES}

1. Ross R. Atherosclerosis--an inflammatory disease. N Engl J Med. 1999;340(2):115-26.

2. Oliveira $C L$, Fisberg M. Obesidade na infância e adolescência: uma verdadeira epidemia [Obesity in children and adolescent: a true epidemiology]. Arq Bras Endocrinol Metab. 2003;47(2):107-8.

3. Mendis S, Lindholm LH, Mancia G, et al. World Health Organization (WHO) and International Society of Hypertension (ISH) risk prediction charts: assessment of cardiovascular risk for prevention and control of cardiovascular disease in low and middle-income countries. J Hypertens. 2007;25(8):1578-82.

4. Baena CP, Chowdhury R, Schio NA, et al. Ischaemic heart disease deaths in Brazil: current trends, regional disparities and future projections. Heart. 2013;99(18):1359-64.

5. Ferraz ML, Nascimento DM, Rorato JP, et al. Correlation of lifetime progress of atherosclerosis and morphologic markers of severity in humans: new tools for a more sensitive evaluation. Clinics (Sao Paulo). 2012;67(9):1071-5.

6. Thom T, Haase N, Rosamond W, et al. Heart disease and stroke statistics--2006 update: a report from the American Heart Association Statistics Committee and Stroke Statistics Subcommittee. Circulation. 2006;113(6):e85-151.

7. Romaldini CC, Issler H, Cardoso AL, Diament J, Forti N. Fatores de risco para aterosclerose em crianças e adolescentes com história familiar de doença arterial coronariana prematura [Risk factors for atherosclerosis in children and adolescents with family history of premature coronary artery disease]. J Pediatr (Rio J). 2004;80(2):135-40.

8. Williamson DF, Madans J, Anda RF, et al. Recreational physical activity and ten-year weight change in a US national cohort. Int J Obes Relat Metab Disord. 1993;17(5):279-86.

9. Lis $\mathrm{S}$, Chen W, Srinivasan SR, et al. Childhood cardiovascular risk factors and carotid vascular changes in adulthood: the Bogalusa Hearth Study. JAMA. 2003;290(17):2271-6.

10. Coutinho W. Consenso Latino-Americano de Obesidade [Latin America consensus on obesity]. Arq Bras Endocrinol Metab. 1999;43(1):21-67.

11. Chinn S, Rona RJ. Prevalence and trends in overweight and obesity in three cross sectional studies of British Children, 1974-94. BMJ. 2001;322(7277):24-6.

12. Leão LSCS, Araújo LMB, Moraes LTLP, Assis AM. Prevalência de obesidade em escolares de Salvador, Bahia [Prevalence of obesity in school children from Salvador, Bahia]. Arq Bras Endocrinol Metab. 2003;47(2):151-7.

13. Holmbäck U, Fridman J, Gustafsson J, et al. Overweight more prevalent among children than among adolescents. Acta Paediatr. 2007;96(4):577-81.

14. Petersen S, Brulin C, Bergström E. Increasing prevalence of overweight in young schoolchildren in Umeå, Sweden, from 1986 to 2001. Acta Paediatr. 2003;92(7):848-53.

15. Dietz WH. Periods of risk on childhood for the development of adult obesity--what do we need to learn? J Nutr. 1997;127(9):1884S-1886S.

16. Brasil. Instituto Brasileiro de Geografia e Estatística. Sinopse do Censo demográfico 2010. População residente, total, urbana total e urbana na sede municipal, em números absolutos e relativos, com indicação da área total e densidade demográfica, segundo as Unidades da Federação e os municípios-2010. Available from: http://www.censo2010.ibge.gov. br/sinopse/index.php?uf=31. Accessed in 2014 (Nov 18).

17. Santos RD. III Diretrizes Brasileiras Sobre Dislipidemias e Diretriz de Prevenção da Aterosclerose do Departamento de Aterosclerose da Sociedade Brasileira de Cardiologia [III Brazilian Guidelines on Dyslipidemias and Guideline of Atherosclerosis Prevention from Atherosclerosis Department of Sociedade Brasileira de Cardiologia]. Arq Bras Cardiol. 2001;77(supl. 3):1-48.

18. Suñé FR, Dias-da-Costa JS, Olinto MTA, Pattussi MP. Prevalência e fatores associados para sobrepeso e obesidade em escolares de uma cidade no Sul do Brasil [Prevalence of overweight and obesity and associated factors among schoolchildren in a southern Brazilian city]. Cad Saude Publica. 2007;23(6):1361-71. 
19. Bolzan A, Guimarey L, Frisancho AR. Study of growth in rural school children from Buenos Aires, Argentina using upper arm muscle area by height and other anthropometric dimensions of body composition. Ann Hum Biol. 1999;26(2):185-93.

20. de Onis M, Onyango AW, Borghi E, et al. Development of a WHO growth reference for school-aged children and adolescents. Bull World Health Organ. 2007;85(9):660-7.

21. Casey VA, Dwyer JT, Berkey CS, et al. The distribution of body fat from childhood to adulthood in a longitudinal study population. Ann Hum Biol. 1994;21(1):39-55.

22. Freedman DS, Serdula MK, Srinivasan SR, Berenson GS. Relation of circumferences and skinfold thicknesses to lipid and insulin concentrations in children and adolescents: the Bogalusa Heart Study. Am J Clin Nutr. 1999;69(2):308-17.

23. Falkner B, Daniels SR. Summary of the Fourth Report on the Diagnosis, Evaluation, and Treatment of High Blood Pressure in Children and Adolescents. Hypertension. 2004;44(4):387-8.

24. Brasil. Instituto Brasileiro de Geografia e Estatística. Pesquisa de orçamentos Familiares 2008-2009. Tabela de composição nutricional dos alimentos consumidos no Brasil. Rio de Janeiro: IBGE; 2011. Available from: http://www.ibge.gov.br/home/estatistica/ populacao/condicaodevida/pof/2008_2009_composicao_ nutricional/pofcomposicao.pdf. Accessed in 2014 (Nov 19).

25. American Diabetes Association, Bantle JB, Wylie-Rosett J, et al. Nutrition recommendations and interventions for diabetes: a position statement of the American Diabetes Association. Diabetes Care. 2008;31 Suppl 1:S61-78.

26. Sociedade Brasileira de Cardiologia; Sociedade Brasileira de Cardiologia; Sociedade Brasileira de Pediatria; et al. I Diretriz de Prevenção da Aterosclerose na Infância e na Adolescência. Arq Bras Cardiol. 2005;85(supl. 6):3-36.

27. Institute of Medicine (US) Subcommittee on Interpretation and Uses of Dietary Reference Intakes, Institute of Medicine (US) Standing Committee on the Scientific Evaluation of Dietary Reference Intakes. DRI Dietary Reference Intakes: Applications in Dietary Assessment. Washington: National Academies Press; 2000.

28. Coronelli CL, de Mourab EC. Hipercolesterolemia em escolares e seus fatores de risco [Hypercholesterolemia and its risk factors among schoolchildren]. Rev Saude Publica. 2003;37(1):24-31.

29. Barja S, Barrios X, Arnaiz P, et al. Niveles de lípidos sanguíneos em escolares chilenos de 10 a 14 años de edad [Blood lipids in Chilean children 10-14 years of age]. Nutr Hosp. 2013;28(3):719-25.

30. Bucher BS, Tschumi S, Simonetti GD. [Childhood's determinants for high blood pressure in adulthood]. Ther Umsch. 2012;69(5):295-8.

31. Rover MRM, Kupek E, Delgado RCB, Souza LC. Perfil lipídico e sua relação com fatores de risco para a aterosclerose em crianças e adolescentes [Lipid profile and its relationship atherosclerosis risk factors in children and adolescents]. Rev Bras Anal Clín. 2010;42(3):191-5.
32. Costa JV, Silva ARV, Moura IH, et al. Análisis de los factores de riesgo para hipertensión arterial en adolescentes escolares [An analysis of risk factors for arterial hypertension in adolescent students]. Rev Latinoam Enferm. 2012;20(2):289-95.

33. Scherr C, Magalhães CK, Malheiros W. Análise do perfil lipídico em escolares [Lipid profile analysis in school children]. Arq Br Cardiol. 2007;89(2):73-8.

34. Moser DC, Milano GE, Brito LMS, Titski ACK, Leite N. Pressão arterial elevada, excesso de peso e obesidade abdominal em crianças e adolescentes [High blood pressure, overweigth and abdominal obesity in children and adolescentes]. Rev Educ Fis. 2011;22(4):591-600.

35. Silva JEF, Giorgetti KS, Colosio RC. Obesidade e sedentarismo como fatores de risco para doenças cardiovasculares em crianças e adolescentes de escolas públicas de Maringá, PR. Revista Saúde e Pesquisa. 2009;2(1):41-51. Available from: http://www.cesumar.br/ pesquisa/periodicos/index.php/saudpesq/article/viewFile/868/721. Accessed in 2014 (Oct 16).

36. Expert Panel on Integrated Guidelines for Cardiovascular Health and Risk Reduction in Children and Adolescents; National Heart, Lung, and Blood Institute. Expert panel on integrated guidelines for cardiovascular health and risk reduction in children and adolescents: summary report. Pediatrics. 2011;128 Suppl 5:S213-56.

37. Grillo LP, Crispim SP, Siebert AN, et al. Perfil lipídico e obesidade em escolares de baixa renda [Lipid profile and obesity in low income school children]. Rev Bras Epidemiol. 2005;8(1):75-81.

38. Halpern A, Mancini MC, Magalhães ME, et al. Metabolic syndrome, dyslipidemia, hypertension and type 2 diabetes in youth: from diagnosis to treatment. Diabetol Metab Syndr. 2010; 2:55.

39. Vásquez F, Díaz E, Lera L, et al. Impacto del ejercicio de fuerza muscular en la prevención secundaria de la obesidad infantil; intervención al interior del sistema escolar [lmpact of strength training exercise on secondary prevention of childhood obesity; an intervention within the school system]. Nutr Hosp. 2013;28(2):347-56.

\section{Sources of funding: None}

Conflict of interest: None

Date of first submission: May 23, 2014

Last received: November 9, 2014

Accepted: December 4, 2014

\section{Address for correspondence:}

Mariana Carvalheiro Cotrim Lima

Av. Vereador João Batista da Costa, 200

Santana — Santa Rita do Sapucaí (MG) — Brasil

CEP 37540-000

Tel. (+55 35) 3473-0156

Cel. (+55 35) 9188-2117

E-mail: marianacarvalheiro@yahoo.com.br 